\section{British Gurkha Recruitment and Higher Education of Gurung Young Men}

Shibaji Gurung

\section{Abstract}

The Gurungs have historical attachment with British Gurkha recruitment and some special social values about it have been developed. So, lahure practice has been developed as a culture among them. This research has tried to analyze the impact of British Gurkha recruitment on the higher education of Gurung young men. The social value of being a lahure and an educated professional in the Gurung community is a major discourse of the study. The study is based on the field work carried out in Pokhara Sub-metropolis. It is basically qualitative in nature and interview was adopted as the main tool to collect the necessary information. Being a lahure is a matter of great craze among the Gurung youths. The socio-cultural circumstances also encourage them to try for recruitment. There is high social value of being a lahure in the Gurung community in contrast with getting higher education. The educational attainment of the Gurung youths is inter-related with these social values. It has an adverse effect on the educational status of the Gurung youths. The educational achievement of the Gurung community would have been far better if the community was not dominated by the pro-lahure culture.

Keywords: Lahure, Gurung, social value, educational achievement, profession

\section{Introduction}

A large portion of Nepalese people have been engaged in foreign employment since a long time. British Gurkha recruitment is the oldest form of foreign employment. Gurung is an important ethnic group of western hills who have been involved in British Gorkha army since 1815/16 A.D. Due to the long history of involvement in the army; lahure ${ }^{1}$ practice has been developed as a culture among the Gurungs. Moreover, it has been a major source of livelihood among the community. It is often stated that there is at least a lahure in a Gurung household and a civil servant in a Brahmin household. So, lahure profession is heavily practiced in Gurung community. The number of recruitment in the British army has decreased these days but its charm is as such among the Gurungs. Although their bravery is renowned all over the world, the Gurungs have not been able to have remarkable achievement in the educational sector. There has been much discussion about the importance of remittance brought by British Gurkha army. But the impact of the recruitment on the educational sector is not talked enough. So, it is necessary to have a discourse on the interrelation of British Gurkha recruitment and the educational achievement of the Gurungs.

The history of the involvement of the Gurungs in the British army is nearly two century long and lahure practice has been transferred as a traditional profession from generation to generation. This traditional profession is considered as a prestigious profession in the community. So, some special social values about it have been developed with in their community. The research has tried to describe the dimension of such social value. It has also tried to analyze how much social value the Gurung community gives to British Gurkha recruitment in contrast with education. British Gurkha recruitment has social, political and economic implications on the recruiting communities (Des Chene, 1991; Caplan, 2003). Education is also not far away from the influence of the recruitment. As boys are only recruited in the British Gurkha army, this research has tried to explore the impact of the recruitment on the higher education of Gurung young men.

A lahure occupies a high social status in the Gurung community. The pro-lahure socio-cultural circumstances encourage the Gurung young men to recruit in the British Gurkha Army instead of achieving higher education. Every year a significant portion of

\footnotetext{
${ }^{1}$ The person who serves in foreign army. In this paper, it refers to the person recruited in British Gurkha army.
} 
Gurung young men attempt to recruit in the British Gurkha Army and only a few of them get success. The preparation process for the recruitment and the consequences caused by the failure in the recruitment adversely affect the higher studies of the Gurung youths. British Gurkha recruitment may be one of the important reasons for the less representation of the Gurungs in the higher education of Nepal. The other remaining part of the paper consists of seven sections which are structured as follows. At first, the research methodology used in the study is described. Then, it consists of a short description of the Gurungs and their educational status. The next section is about the historical background of British Gurkha recruitment. It also describes about the involvement of the Gurungs in it. After this, the next section describes why the Gurungs are attracted for the recruitment in the British Gurkha army. Then, the main part of the paper starts in which the social value given by the Gurung community to the British Gurkha recruitment and education is briefly described in a comparative way. This section is followed by the analysis of the impact of the recruitment on higher education of the Gurung young men and lastly the paper ends with a conclusion.

\section{Methodology}

The research is about the British Gurkha recruitment and higher education of the Gurung young men. For the purpose of this study, Pokhara sub-metropolis of Kaski district is selected as the study area. Kaski district is a historic region for British army recruitment and one of the main areas from which overseas labour migration takes place. Pokhara sub-metropolis is selected as the study area because it is the densely populated city of the Gurung community and it is the place from where heavy recruitment in British Gurkha recruitment takes place. The historical development of British Gurkha recruitment is well described with the help of a lot of literature review and some archival works.

Mostly, the data collected are qualitative in nature. Interview was adopted as the main technique to collect data from the respondents. There were different types of respondents which include: school, $10+2$ and campus level's Gurung students, their parents, Gurung youths preparing for British army recruitment, British lahure,
Gurung girls, ex-British lahure, chief/representative of Gurung social organization and Gurung educated professionals. A sufficient number ${ }^{2}$ of persons (4-10) from each of the above categories were purposively selected for the interview process. The names of the respondents are not disclosed in this article to protect their identity. The interview with these categories of persons helped to know different aspects of British Gurkha recruitment and education practiced among the Gurung community. The social values of British Gurkha recruitment and education were discussed in the interview. The impact of such social values on the higher education of Gurung men was a major portion of discussion in the interview. Along with interviews, the activities of the trainees for the recruitment were closely observed in Pokhara. The first phase of field work was carried out from $17^{\text {th }}$ July to $16^{\text {th }}$ August, 2010 and the second phase was carried out from $20^{\text {th }}$ October to $10^{\text {th }}$ November, 2010.

\section{Gurung and their educational status}

Gurung is one of the dominant ethnic groups of western hills. They are Tibeto-Burman speaking people. "It is mentioned in the Paye $\mathrm{Ta} \mathrm{Lu} \mathrm{Ta}{ }^{3}$ that the Gurungs have been migrated from Mongilia to China (Tibet) and then towards Gandaki region of Nepal through Mustang" ("Gurung” Thakali, 2067 V.S:111). Their population is mainly concentrated in the Gandaki region. "Gurung country lies in the high valley of the Southern slopes of the Annapurna Chain and of Himchuli in the central region of high hills" (Pignede, 1999:4). Beside the homeland, they have spread out up to Kathmandu valley, eastern part and all over the country. Agriculture and livestock rearing are their main traditional occupations. Women often involve in weaving and men engage in basketwork using bamboo. Beside these, lahure and other foreign employment are important source of livelihood among Gurung community. Religiously, they follow Buddhism and Bonism. They have three priests: Lama, Pachayu and Klihbri. The most important ritual and

\footnotetext{
2 The number of respondents ranged from 4-10. It was considered sufficient when the adequate data was available with that number. 3 Gurung's mythology.
} 
festival of Gurung are Pai ${ }^{4}$ and Lo-shar ${ }^{5}$ respectively. According to the population census of 2001, the total population of Gurung is 5 , 43,571 which comprises $2.39 \%$ of the total population of the country and its population in the Pokhara sub-metropolis is 33,795 which comprises $21.62 \%$ of the total population of the submetropolis (CBS, 2001). Although significant in number, they are educationally backward. The Human Development Report of 2004 shows that $57.61 \%$ of Gurungs are literate, $1.98 \%$ have passed up to S.L.C. and equivalent, $1.62 \%$ have passed up to certificate level and equivalent and only 1.07 are graduates and above (UNDP, 2004: 175). These data show that the educational status of Gurung is poor and there is less representation in higher education. Gurung (2005), in his baseline study, explores the status of Gurung of Pokhara in higher education. He has compared the enrolment, performance and drop out of Gurungs with non-Gurungs. He found that the enrollment and result of Gurung students in different faculties of Tribhuvan University and Pokhara University is comparatively low than the non-Gurung students. The drop-out rates of Gurung student is higher than the non-Gurung student which is depicted in the table1.

Table1. Dropout of Gurungs/Non-Gurungs in Bachelor Level

\begin{tabular}{|c|c|c|c|c|c|c|}
\hline \multirow{2}{*}{ University } & \multirow{2}{*}{ Level } & \multirow{2}{*}{$\begin{array}{c}\text { Academic } \\
\text { Year }\end{array}$} & Enrolment & $\begin{array}{c}\text { App. } \\
\text { last } \\
\text { Exam }\end{array}$ & $\begin{array}{c}\text { No of } \\
\text { Dropout }\end{array}$ & $\begin{array}{c}\text { \% } \\
\text { Dropout }\end{array}$ \\
\hline $\mathrm{TU}^{6}$ & Bachelor & $2061 / 064$ & 2527 & 1652 & 875 & 35 \\
\hline $\mathrm{PU}^{7}$ & Bachelor & $2060 / 064$ & 174 & 123 & 51 & 29 \\
\hline & & & \multicolumn{5}{|c|}{ Gurung } \\
\hline $\mathrm{TU}^{8}$ & Bachelor & $2061 / 064$ & 369 & 169 & 200 & 54 \\
\hline $\mathrm{PU}^{9}$ & Bachelor & $2060 / 064$ & 43 & 23 & 20 & 46 \\
\hline
\end{tabular}

Source: Gurung 2065 V.S.

\footnotetext{
${ }^{4}$ Funeral ceremony of Gurung.

${ }^{5}$ New Year of Gurung.

6 It covers all the affiliated and constituent campus of Tribhuwan University located in Pokhara sub-metropolis.

${ }^{7}$ It covers all the affiliated colleges of Pokhara University located in

Pokhara sub-metropolis and the central university campus of Lekhnath municipality near by Pokhara sub-metropolis.

8 It covers all the affiliated and constituent campus of Tribhuwan University located in Pokhara sub-metropolis.

${ }^{9}$ It covers all the affiliated colleges of Pokhara University located in

Pokhara sub-metropolis and the central university campus of Lekhnath municipality near by Pokhara sub-metropolis.
}

In the above table, the drop out rate of the Gurung students with non-Gurung students in Pokhara studying in TU and PU at bachelor level is compared. The drop outs percentage of nonGurung students at TU is 35\% while that of the Gurung students is $54 \%$. Similarly, the drop outs percentage of non-Gurung students at PU is $29 \%$ while that of Gurung students is $46 \%$. These data show that the drop out percentage of Gurung students is higher than non-Gurung students. Although both Gurung and non-Gurung students are studying in the same academic environment of the same colleges of TU and PU, the differences in the drop out rates may be caused by the specific socio-cultural circumstances that they receive in their particular community. The specific sociocultural circumstances which are causing the drop out of the Gurung students in higher education is described in detail in the later part of the paper.

\section{British Gurkha recruitment and the involvement of Gurungs}

Literally, Lahure means "person of Lahore". "The term most commonly used for a solider who serves or has served in foreign armies is Lahure, a corruption of Lahore, the city in Punjab where, even before they took service with the British, many Nepalese were enlisted into the Sikh army of Ranjit Singh" (Singh, 1962:119; cited in Caplan, 2003:15). The British, at first, recruited Nepali during the Anglo-Nepal war as they were highly impressed with their bravery and military skill. At that time they had raised four battalions from the Gurkha forces. "These first Gurkhas were acquired in one of the two ways: they were either taken prisoners and subsequently offered employment or they deserted and came into the British camps seeking to take service with their erstwhile enemies" (Des Chene, 1991: 49). Afterwards, the British agents informally started to recruit young Nepalese from different parts of the country. Jang Bahadur Rana, who came to power in Nepal in 1846 A.D., helped the British Regime by providing Nepalese contingent in the Bengal's rebellion of 1857 A.D. However, there were several misunderstandings between the Rana regime and British about the Gurkha recruitment. Janga Bahadur Rana restricted the flow of Gurkhas to India and his successors also continued it. "Matters only really improved for the British in the 
last quarter of the nineteenth century when the regime of Bir Shamser took over in Kathmandu. The British threatened to support his rivals for power, the sons of Jang Bahadur, and faced with such an alternative, Bir Shamsher, 'reluctantly gave in'” (Rose and Fisher, 1970: 147; cited in Caplan, 2003:29). There was interdependence between the Rana regime and the British. The Rana regime was dependent on the British for arms and European luxury goods and on the other hand, the British were dependent to Nepal for Gurkha soldiers. This interdependency led for the friendly relation of Nepal's government and the British. Thus, after 1884, the Gurkhas were heavily recruited in British army without any restriction. During First World War and Second World War, Gurkhas were heavily recruited and they showed great bravery in both world wars. According to Banskota (1994), 55,000 recruits were supplied to British in First World War and about 1, 10,000 recruits in the Second World War. With the independence of India in 1947, it was decided that the Gurkha regiments would be divided between the British and new Indian armies. The tri-party agreement of 1947 allowed both Britain and India to continue to recruit Gurkhas. The Brigade of Gurkhas was established in the British army. Within the month of establishment, the Brigade of Gurkhas was involved in jungle warfare against the guerrilla forces of the Malaya Communist Party. The "Malaya Emergency" lasted for twelve years from 1948-60. After that the Brigade was involved in Brunei operation from 1962-1966. The headquarters of the Brigade of Gurkhas was moved to Hong Kong in 1971. During the late years, the Gurkhas were involved in some warfare such as Falkland War (1982) and Gulf War (1991), in which, they showed their bravery as earlier. After the withdrawal of Brigade of Gurkhas from Hong Kong in 1997, there has been reduction in the size of Gurkha soldiers. Nowadays, only about 250 Nepalis are recruited in the British Army every year. During the recent years the Gurkhas are deployed in different parts of the world for peace establishment under the command of NATO. The Gurkhas were deployed in Bosnia (1996), Kosovo (1998/2002), East Timor (1999) and currently they are deployed in Iraq and Afghanistan. Where ever may be the place and whenever may be the time, the Gurkhas have been keeping up the history of bravery.
Gurung has a long military history."During the reign of Prithvi Narayan (1742-1774), they played an important part in the conquest of Nepal. At the time of the occupation of Nuwakot and the Valley of Kathmandu, Magars, Gurungs and Khas formed the majority of the invading troops" (Pignede, 1996:18). In the post unification period, Gurung comprised a major portion of the Nepal army. The Kali Bahadur regiment was solely formed from the Gurung Soldiers. Apart from the Nepalese army, the person recruited in British army also mainly belongs to hill ethnic groups. "The British officers gave priority for Matuwali jati in recruitment. Among them also they have keen interest on Gurungs and Magars. After that they prefer to select kirat groups like Rai, Limbu and Sunawar" (K.C., 2062 V.S:12). The British were influenced with the ideology of 'martial race'. Onta (1996) states that the social truth about the "martial races" of Nepal was practiced in recruiting Gurkhas. So, a certain types of Nepalis from certain places inside Nepal were identified as a proper Gurkha regiments. He further states that Magars and Gurungs from the central Nepal were considered as the best raw materials for the recruitment than their counterparts in east Nepal. After 1980, Rais and Limbus were also gradually recruited in the army. Hence, Gurung belongs to an important component of British Gurkha army since the beginning of the recruitment. Today also, a major portion of British Gurkha army is comprised of Gurung soldiers. Every year many Gurungs recruit in the British army.

\section{Reasons for the recruitment in British Gurkha Army}

The involvement of Gurungs in the British Gurkha army was not only high in the earlier days but it also prevails in the present day. Most of the respondents showed their positive attitude to join the British Gurkha Army. Yearly, thousands of Gurung boys attempt for it. They perform hard training to meet it. They give up everything including their study to recruit in the army. So, there is a kind of craze among the Gurung boys to recruit in the British Gurkha Army.

There are several reasons for the involvement of Gurungs in the army. Livelihoods of many Gurungs are dependent on the lahure income and there are some socio-cultural relations of Gurungs with 
the recruitment. The often stated reason for the recruitment is high income and lifelong pensions. A British Lahure earns up to about $£ 1500$ per month which is comparatively very high than the average income of Nepalese people. One Gurung youth studying B.B.S I ${ }^{\text {st }}$ at P.N campus who is preparing for the recruitment says: There is high income in British army. Its other facilities are also good. My family economic background is poor. I am the senior son. So, if I can become lahure I would improve the economic condition of my family. ${ }^{10}$

If one is successful to be recruited in the British Gurkha army, he could easily improve the life of his whole family. Caplan (2003) talks about the economic implication of Gurkha service. He states that the Gurkhas use their income for repaying old debts, purchase land, build fine houses and provide loans in the local community. Thus, the living standard of the family with their member in the Gurkha service is becoming high. Beside the income, there is much importance of the pension. The person retired from British Gurkha army receives a handsome pension throughout his life. In case of death of a pensioner, his wife can receive it. The life of the exBritish Gurkha army is supported by this pension. They often say, "We can survive without working by the pension". So, this pension attracts many young men to recruit in British Gurkha army. Recruitment in the British Gurkha army is supposed to be related with the secure life. Many of the Gurung youths say, "If one succeeds to become lahure, then life bancha". Here, "Life bancha" means their life will be secured and fruitful. Nowadays, as the British Gurkha army retires, they can have settlement in the U.K. So, the dream of future life in the U.K. attracts many Gurung boys for recruitment in the army. Many Gurung youths argue that there are not good employment opportunities in Nepal. One Gurung British lahure who is on leave states his reason to be lahure as:

There is no job in our country even if we study up to

higher level. All the jobs are dominated by Brahmins and

Chhetris and we don't have link for the job. So, it's very hard for us to find job in Nepal. ${ }^{11}$

The other person who is currently in British Gurkha service says:

\footnotetext{
10 Interview taken on $15^{\text {th }}$ August, 2010, Pokhara

11 Interview taken on $14^{\text {th }}$ August, 2010, Pokhara.
}

I would not have joined the army if there was good job in Nepal. Being lahure is not only our desire rather it's our compulsion. What can we do here without not being lahure or going abroad? ${ }^{12}$

Nepal's bureaucracy is dominated by Brahmins and Chhetries. So, there is a kind of psychology among the Gurungs that the jobs in Nepal are not for them. Historically, they have been affiliated with British Gurkha army. So, they prefer to become lahure or have overseas employment.

When a Gurung boy passes the S.L.C. and becomes eligible for the recruitment, then he starts trainings to prepare for the recruitment process. Hundreds of boys can be seen running in the street of Pokhara and inside the Rangasala ${ }^{13}$ for trainings. More than a dozen training centers operate the training and coaching classes for the youths preparing for the recruitment. There is a kind of wave among the Gurung youths to do such trainings. As many friends and relatives are having training for the recruitment, one is easily attracted towards it. A young man found inside the Rangasala says;

I don't have keen interest to join the army. But I am here for training following my friends. Let's see, what happens? If I succeed, it will be o.k. ${ }^{14}$

Beside the above reasons, the important reason for the recruitment of Gurungs in the British Gurkha army is the socio-cultural circumstances. Among the different cultural aspects of Gurung, Lahure practice is an important one. The socio-cultural circumstances encourage the Gurung young men for the recruitment. The children psychology is influenced by lahure since their early age. They grow up listening to the stories of bravery of their father and forefather. They are attracted with the life style of the army. A Gurung youth who attempted many times for recruitment and unfortunately failed, remembers his dream to be lahure as;

\footnotetext{
12 Interview taken on $9^{\text {th }}$ November, 2010, Pokhara.

13 Stadium of Pokhara city.
}

14 Interview taken on $14^{\text {th }}$ August, 2010, Pokhara. 
My father is an ex-Gurkha army. So, I was interested to join the army since my childhood. I used to dream how the army dresses, that hat, medals and that boot would suit me. ${ }^{15}$

On the occasional ceremonies, the senior bless their children to become lahure and to gain higher posts such as Laptain, Captain etc. As lahure has been practiced among Gurung since the historical time, it is like a tradition for them. Many Gurung youths still try to continue the profession of their father and forefathers. They perceive lahure practice as a continuity of their tradition. A British Gurkha lahure occupies a high social status in Gurung community. So, many youths want to become lahure. The parents also encourage their children to be lahure. A Gurung student studying B.B.S. $2^{\text {nd }}$ year at Jana Priya Multiple Campus says:

My parents wish me to become lahure. They always ask what the utility of studying is. They argue that I can earn more by becoming a lahure. ${ }^{16}$

So, the Gurung boys are encouraged for recruitment in British army instead of studying. Sometimes the parents even put pressure on their son to try for the recruitment. A Gurung student studying M.A. at P.N. campus remembers his days while attempting for recruitment as:

I didn't have any interest to become lahure. But I tried it once due to the pressure of my family. At that time my father used to say there is no future in Nepal just by studying. He used to convince me that I can have better and happy life if I succeed to join the British army. ${ }^{17}$

The socio-cultural circumstances among the Gurung community are pro-lahure. All these socio-cultural circumstances encourage Gurung youths for the recruitment. So, many Gurung youths are attracted in British Gurkha army.

\footnotetext{
15 Interview taken on $25^{\text {th }}$ October, 2010, Pokhara.

16 Interview taken on $23^{\text {rd }}$ July, 2010, Pokhara.

17 Interview taken on $21^{\text {st }}$ July, 2010, Pokhara.
}

\section{Social value of British Gurkha recruitment and education among the Gurungs}

Social value is a constituent part of a culture of any society. It is the measurement of goodness or desirability. "Cultural values are these collective conceptions of what is considered good, desirable and proper-or bad, undesirable and improper- in a culture. They indicate what people in a given culture prefer as well as what they find important and morally right (or wrong)" (Schaefer, 2003:69). Men always pursue for good or desirable things. So, value always guide for the behavior of the people. "Values are the criteria people use in assessing their daily lives, arranging their priorities, measuring their pleasure and pains, choosing between alternative courses of action”(Rao, 1990:469). The value system differs according to the culture of the society. It is developed on the background of specific social circumstances of the particular society.

Gurung community gives high social value to Lahure. Most of the respondents stated that such social value is more than that of an educated professional. Handsome salary, life long pensions and the knowledge that they acquire while travelling aboard are some important reasons for such social value. When a lahure returns back to his home on leave, he receives a kind hospitality. He is warmly welcomed everywhere and invited by his relatives for lunch and dinner. This is an opportunity to share the news and experience of locality and abroad. When a lahure is on leave, it is marked with a gift-giving. Lungi, shawls, sweater, t-shirts, watches etc are offered as gifts to both consanguineal and affinal kin. This kind of gift-giving renews the relationship of a lahure with his relatives and it also increases the prestige of the lahure. When a lahure goes to his village, the young people gather around and perform singing and dancing in honour of lahure. Thus, a lahure receives a high respect during his leave. This high social status still continues after they return back to their home. They become popular by their position that they had received in the army such as Laptain Sahab, Captain Sahab, Hawaldar Sahab etc. When there is necessity of any leading role in local organization, then the exarmy of the higher rank are given that opportunity. It is because they think that he has acquired much knowledge while travelling 
aboard and as he had lead in the army, he could easily lead the organization. So, the ex-British army occupies important roles such as village chairman, chairman of school management committee, chairperson in the local development committee and other social organizations.

The social value of British lahure among the Gurung community in the 1980's can be judged from the blessings that the elders give on occasions. Des Chene writes:

On occasions when young children are blessed with tika,

the wishes that often go with it are these: For a boy, to

become big and strong and become a Hong Kong lahure and for a girl, to grow up to marry a Hong Kong lahure. These wishes are light hearted, but they are nevertheless telling. In wishing the best for their children, lahure stands for luck, wealth and opportunity (Des Chene, 1991: 244).

Even today, this type of blessing is often heard in the Gurung community. Many Gurung boys responded that they are still receiving such kind of blessings. Mainly grandfather and grandmother give such blessings to their grandson. Some of the other parents wish for the better education of their children. This shows that there is changing perception about lahure and some of them have thought to make their son other than lahure. But still many wish to make their son a British lahure. There is also preference for a lahure in case of marriage. When there is discussion about the marriage the profession of would-be bridgegroom is asked as whether he is lahure or chaure ${ }^{18}$. The other category of persons than lahure belongs to Chaure who are staying and working in the home country. In this case, a lecturer at P.N. Campus in Pokhara who is closely familiar to the Gurung community puts his opinion as:

The first preference in case of marriage is British lahure, the second one is I.D. holders of Hong-Kong and the U.K., and the third priority goes to Indian army and other overseas employee. The educated professionals and the

18 Persons who are not recruited in foreign army and staying and working in the home country. They are regarded as low category people in Gurung community. other persons working in own country is not given much value. ${ }^{19}$

Most of the parents would be happy if they marry their daughter with a British lahure. So, when an unmarried lahure is on leave at home he receives many proposals from their relatives. A British lahure who is on leave states:

I have been receiving many proposals since my arrival. My aunt, sister and other relatives have been forcing me to get married. I have been escaping from them as I have my own girlfriend whom I am going to marry. ${ }^{20}$

British lahure are highly preferred in case of marriage because of high income, lifelong pensions and secure life in the U.K. Though the parents prefer British lahure and there are many proposals for a British lahure on leave, Gurung girls of the present time seem not so much attracted towards lahure. ${ }^{21}$ Some of the respondents prefer to marry with educated professionals and some other argue whatever may be the profession the most important thing for them is that their would-be husband should understand them. Due to the growing awareness and educational achievement, Lahure is not a matter of great craze among modern Gurung girls. However, the community still prefers British lahure in case of marriage and he can easily marry even with a graduated girl. ${ }^{22}$ Being lahure has been practiced as a culture in Gurung community. Every

19 Interview taken on $14^{\text {th }}$ August, 2010, Pokhara.

20 Interview taken on $27^{\text {th }}$ October, 2010, Pokhara.

${ }^{21} 5$ Gurung girls of marriage age were interviewed to know their preference of would-be husband. This small number of Gurung girls may not represent the opinion of whole Gurung girls. Moreover, during the interview, they hesitated to speak frankly due to the sensitive nature of the question. In order to finalize this issue, there is necessity of a good survey regarding the preference of Gurung girls for marriage. But due to the qualitative nature of the research and other limitations it was not

possible in this research.

${ }^{22}$ Though it was not clear from the interview with Gurung girls, the opinions of the parents, other respondents and the experience of the lahure clarifies it. Moreover, the researcher himself is from Gurung community and apart from the research period, he has been observing frequent cases that lahure are preferred for marriage in the Gurung community. So, it can be pointed out that there is preference of a lahure for marriage in the Gurung community. 
community prefers their culture. The living standard of British lahure is high than that of other Gurung professionals. They have beautiful houses in the town of Pokhara and having luxurious life. Their children are studying in private schools and colleges. The expenses in cultural ceremonies such as funeral ceremony, marriage ceremony etc. is very high in Gurung community and it's very hard for a normal middle-class people to afford it. During the process of marriage and funeral ceremony, whatever is given is noted down and when the giver performs such ritual in his household, then a return of exact value is made. The process of giving the sum of money or commodities in such ritual is regarded as syai syai. The commodities brought by a lahure were used in the rituals with a great significance during 1980's. Des Chene writes:

Items of exchange in the most important ritual contexts marriages and funerals have remained quite fixed despite the influx of goods brought back by lahores. The foods contributed remain locally produced items. The items exchanged between affines and parallel kin of the deceased remain the traditional kregi kramo(turbans for men, shawls for women), but the shawls are now imported ones of the sort that lahores bring home, and to them have been added lungis from Hong Kong and Indonesia. Inflation and the addition of these foreign goods have made the pae very expensive for the patriline of the deceased, and it is certainly easier for those with a lahore in the immediate family to meet these obligation (Des Chene, 1991: 339).

The values of such commodities in the rituals still exist. Moreover, there is increasing competition in performing syai syai in the rituals. Describing the situation, the chairman of the Gurung student organization, Kaski district comments as:

There are a lot of wrong practices in funeral and marriage rituals. There is like a competition who will give more in performing syai syai. I have seen people giving more than five thousand rupees at once. So, it has created a difficult situation for poor people. In order to cover these expenses also, one has to go abroad to earn more. ${ }^{23}$

\footnotetext{
${ }^{23}$ Interview taken on $22^{\text {nd }}$ July, 2010, Pokhara.
}

Those who give a lot of money deserve high status and prestige in the Gurung community. So, there is such kind of unhealthy competition. Lahure or other rich persons can only cope with such situation. Thus, the use of commodities brought by lahure in the rituals and the capacity of a lahure to afford the expenses in such rituals has increased the value of lahure in the community. During the late days there has been heavy increment in the salary, pension and facilities of British lahure. Thus, the value of British Lahure has increased much during these days.

The social value of educated professionals is different than that of lahure in Gurung community. They do not receive as much value as that of British lahure when the value is measured in terms of economy. They are regarded as chaure. The persons working in Nepal can not earn enough. There is always lacking in their daily expenses. In Gurung community, there is expensive life style and high cultural expenses. So, the community mostly seeks for rich person and a British lahure would be a right person to meet all these expectations. There is always comment in the society regarding the income of educated professionals or the persons working in Nepal. One Gurung lecturer shares his experience as:

I am satisfied with my income whatever so. But my

relatives always ask: "How much do you earn? Is it

sufficient? Why don't you go abroad to earn more? "24

Acquiring higher education has different meanings in Gurung community. According to Ragsdale (1989), it is the pass certificates which enable Gurung youth to join the army. In his study, he found that when the New Education plan of 1974 introduced new primary level examinations which acted as a barrier to keep less academically qualified students from passing out of the primary schools, the circumstances of the Gurung society altered the result to meet their expectations. Ragsdale's research shows that the Gurungs of 1980s and earlier perceived education just as a qualification for becoming a lahure. Today, to become a British lahure one needs to be sound educationally too. From 2005 onwards, those who have passed S.L.C. are only

\footnotetext{
${ }^{24}$ Interview taken on $29^{\text {th }}$ October, 2010, Pokhara.
} 
eligible for recruitment. For this reason, Gurungs have given priority for education these days at least up to S.L.C. Apart from this, there is growing awareness among the Gurungs about the importance of education. So, some parents are encouraging their children for achieving higher education. Pettigrew writes:

Although parents are putting inordinate effort into educating their children, there is to date little evidence that education will lead to increased employment opportunities in the near future. Jobs are scare and clerical position in the bureaucracy, towards, which Nepali education is geared remains dominated by Brahmin, Chhetris, and Newars. Many students who have received university level education are unemployed or join the long exodus of those "going to foreign" in search of work (Pettigrew, 2000: 1314).

Thus, the initiatives of some conscious parents also get vain. Nepal's higher educational system has not been fruitful as its graduates have not been successful in obtaining good job opportunities. So, there is always a question: why to study, when there is no job opportunity? This type of question is often heard in the Gurung community which is dominated by lahure culture. So, the Gurungs are not optimistic about the opportunities of higher education and they are inclined more towards lahure or overseas employment.

In spite of pessimism about the opportunity of higher education and less social value, the social organizations of Gurung (Тamu Samaj) have been playing important role to increase awareness about the value of education. These organizations conduct the program in honor of S.L.C. and university graduates every year. Here, the students are congratulated, honored and wished for bright future. Such types of programs help to encourage the Gurung students to continue their higher education studies. The social value about the educated professionals is not always same. It is said that the fruit of hard work is sweet. For a Gurung educated professional he has to face many challenges in the initial period. Even he does not get enough respect. There is always comment why he has not been lahure or gone for overseas employment. But when he succeeds to be a high level educated professional, he is given enough social value. Regarding this situation, one of the established educated professional who is a lecturer at Western Regional Engineering Campus says:

Previously, I was not valued much. But today I am like the centre of their hope. When they suffer any difficulties they come to me. They think that their problem will be solved if I treat it. I am proud to help my people. ${ }^{25}$

A higher education graduated person has more social and political influence than a lahure. They can easily deal with any kind of political or administrative works. So, an educated person is searched for such kinds of work. This has increased the value of educated professionals with in the community. However, this kind of value is only for limited educated professionals who have been successful to establish them-selves at the top level. The overall socio-cultural circumstances of Gurung community do not value as such to all the youths who are building their career as educated professionals. Nowadays, there are many social organizations of Gurung working for the welfare of their community. These organizations conduct various programs in different occasions. Mostly high level educated professionals are invited as chief guest and guests in such programs. Many ex-British armies have realized that they had to suffer in the army as they were not educated. So, they have realized the value of education and started to give good education to their children. There are some cases that some persons even resign from the army and return back to Nepal to continue their higher study. A $10+2$ graduate who served in the British Gorkha army for two years put his opinion as:

Being a lahure was not like what I had thought previously.

I was recruited following my friends. I could not manage time to study there. Every time I had to go to duty. So, I convinced my family and resigned from the army. Now, I am planning to continue my study. ${ }^{26}$

For some persons being a lahure might be different than as thought earlier. They cannot meet their expectations and continue their

\footnotetext{
${ }_{26}^{25}$ Interview taken on $23^{\text {rd }}$ July, 2010, Pokhara.
}

26 Interview taken on $9^{\text {th }}$ November, 2010, Pokhara. 
higher studies. So, some of them even resign from the army. Such type of cases occurs occasionally. This is the symptom of the realization of the importance of higher education within Gurung youth. Thus, it can be concluded that there is also increasing awareness about the importance of education among the Gurung community.

\section{Impact of British Gurkha recruitment on higher education of Gurung young men}

The Lahure culture of Gurung is similar to Magar, Rai, and Limbu to many extents. Rai (2010) has studied about Lahure culture and higher education of Rai community with two approaches: before the recruitment and after the recruitment. He argues that preparation for Lahure competition is the major reason for drop out for the higher education of Rai youths. It is the negative impact of Lahure culture on education of Lahure recruiting community like Rai. He further argues that after joining the Lahure he can do full support to his family and relatives in achieving the higher education. This is the positive impact of Lahure culture in higher education. The Gurkha Ex-Servicemen's Organization (GAESO) campaigns for improved pensions of ex-Gurkha soldier. They also have some demands regarding the welfare of their family. Among these demands, Gould writes:

One is that the British government assists in creating

educational and training institutions for the children of

Gurkhas. Though there are no such facilities for the

children of British, GAESO maintains that since most

Gurkhas are separated from their families for twelve out of

fifteen years' service, their children are deprived of a father

figure and, as a result of this and of the inevitable disruption of the education through travel to and from the

United Kingdom and elsewhere, tend to be 'wayward' (Gould, 1999:389).

The research of Rai (2058 V.S.) also supports this argument. He states that some of the children of Lahure are educated and grown up abroad to some couple of years and when they return back, they can not easily adjust to the local educational system and culture. So, they can not perform well in their study. Hence, the previous studies show some negative as well as positive impacts of British Gurkha recruitment on the recruiting communities.

Gurung is one of the most important communities in which lahure profession is heavily practiced. But this community has less representation in higher education. There is a close relationship between lahure culture and educational achievement of Gurungs. "In the case of Janajati men, recruitment in the British and Indian Armies (Bharti Jane) has been reported as a major cause of their under representation in higher education" (Bhatta et. al., 2008:253). There is a kind of psychology among the Janajati people including Gurung that they are not the group whose job is to study; rather it's a matter for the Brahmins. So, they do not give more emphasis in studying up to higher level. The socio-cultural circumstances of the community are pro-lahure. Such kind of social circumstances discourage the Gurung youths from attaining higher education. Many Gurungs are grown up with a psychology to be lahure in future. So, they do not concentrate much on their study.

Most of the Gurung boys seem to have studied up to S.L.C. in a regular manner. The parents also have full support in it. But when they pass the S.L.C. exam, then they concentrate towards recruitment rather than study. They just focus to study up to S.L.C. because after S.L.C. they become eligible for recruitment. The chairman of a Gurung student organization, Kaski argues as:

The first priority of a S.L.C. passed Gurung boy is to be recruited in the British army, if not then the $2^{\text {nd }}$ priority is Indian army and the third one is only higher education.

During the course of study also, he would be searching for other foreign employment opportunities. ${ }^{27}$

So, higher education is not the priority of most Gurung boys. Sometimes the parents even put pressure on their S.L.C. graduate son to try for recruitment. The person who intends for higher education has to face many challenges. He has to overcome prolahure culture among the community. Thus, the social values

27 Interview taken on $22^{\text {nd }}$ July, 2010, Pokhara. 
developed by lahure culture is hindering in the process of achieving higher education of Gurung young men.

The competition for recruitment is very tough these days. So, one has to work hard in order to qualify for the recruitment. He has to perform well in both physical and mental test. Most of the youths attempting for the recruitment join training centre for the necessary trainings. They spend Rs. 3000 to Rs. 5000 per month for the training. The trainees have tight schedule. They hardly have time for their formal study. Generally, the training starts from 6:00 am early in the morning. Young boys line up in the open ground where the attendance is taken first and the basic instructions are given. Then, they start their trainings with a dream to be lahure in the future. The trainings include running, set up, heaving, army drill etc. The morning training ends at about 8:00 am. After this, they freshen up and have breakfast. Then, they take a tuition class from 9:00 to 10:00 am. Again they take another tuition class in the afternoon from 3:00 pm to 4:30 pm. After this tuition class, they again start their physical trainings from around 5:00 pm to 7:00 $\mathrm{pm}$. Those trainees who are not staying in hostel at the training centre may go home at other times beside trainings and tuition class. Some of them who have college during the day go to attend the classes. But they can not concentrate on the study as they are already tired. One of them who are studying at class 12 shares his experience as:

I can not study well in college. As I am already very tired, I feel sleepy and can not concentrate on what my teacher says. $^{28}$

The heavy exercise and busy schedule makes them very tired. They don't get much time for the study and during the remaining short period of time they can not study well. Some of the trainees totally quit their study during the course of training. They give only priority to the training for recruitment. One of such trainees says:

I am studying in BBS $1^{\text {st }}$ year at P.N. Campus but these days I have stopped my study. If I continue my study and trainings together, I may not succeed in both of them. So, I

\footnotetext{
28 Interview taken on $13^{\text {th }}$ August, 2010, Pokhara
}

have to choose one and training for the recruitment is my priority. $^{29}$

There are many Gurung trainees who are quitting their study in order to get more focused on trainings for the recruitment. Those who are studying side by side along with trainings are also not doing well. The preparation process and competition for the recruitment take a long period of time. Normally, the trainings for the recruitment take place throughout the year. But mostly a large number of youths are engaged in the trainings from about 3-4 months prior the selection of new batch of recruits. Generally, registration for recruitment in the British Gurkha army opens in the month of June and July. The regional selection takes place between August and September and the final selection takes place from the mid of November to the last of December. The process of selection of the recruitment takes a long time of about seven months. So, the candidates who reach up to the final selection have to spend about 8-9 months and others normally spend 4-6 months while competing for the recruitment in the army. As a long period of time is invested for the preparation and competition of the recruitment, these youths can not perform well in their study. Sometimes their exams may also take place within this period and they have to leave them for the sake of the recruitment process. So, the preparation process for the recruitment in British Gurkha army is badly affecting the higher education of Gurung young people.

The preparation process for the recruitment does not only hamper for one academic year but it also affects three or four years in many cases. There are many Gurung youths who try to get recruitment in the British Army for three or four years. Many Gurung youths still do not succeed even by attempting up to three or four times. This kind of practice hamper many academic years of the youth. One of such candidates expresses his feeling as:

Today I am just studying at BBS $1^{\text {st }}$ year but my other

friends are studying at Master's degree level. If I had not lost four years in attempting for lahure I would also have been studying at my friend's level. The process of recruitment ruined my study. Now, I am trying to recover

29 Interview taken on $15^{\text {th }}$ August, 2010, Pokhara. 
my study. But there are still many youths who have been ruining their study and future in hope of becoming lahure. ${ }^{30}$

Many Gurung youths lose a number of academic years in the quest of being lahure. The high dropout percent and poor performance in higher education of Gurung is due to the involvement of a large portion of Gurung youth in the recruiting process of British Gorkha army. An unofficial source states that about fifteen thousand Nepali youths compete for about 250 seats in the British army. ${ }^{31}$ Among them Gurung comprises a major portion. ${ }^{32}$ Those who succeed to join in the British army quit their higher education and go far away from Nepal being a lahure; and thousands of youth who are not selected are left behind. It is very hard for the latter one to recover their study as they had already ruined it during the process of recruitment. Analyzing the situation, a central committee member of Tamu Choj Dhi (Gurung's social organization) comments as:

The British make over ten thousand youths to run and train for about six months and at last only take away about 250 persons. Those who do not succeed gets tired of trainings, they have no excitement to work and study; and get frustrated. So, the recruitment process is hampering the higher education of Janajati youth including Gurungs. ${ }^{33}$

Those who are selected up to the final are very devoted in competition to be a lahure. Unfortunately, if they do not succeed in final, they will be greatly shocked. They get frustrated so much that some of them even do not return back to their home for many days. One of the candidates who failed at the final selection remembers the situation after the result as:

${ }^{30}$ Interview taken on $23^{\text {rd }}$ July, 2010, Pokhara

31 The head office of British Gurkhas Nepal at Man Bhawan, Lalitpur did not provide the exact data of competing and recruited candidates in British Gurkha army. The other unofficial source has stated this data.

32 The head office of British Gurkhas Nepal at Man Bhawan, Lalitpur did not provide the data of caste/ethnic composition of the competing and recruited candidates in British army. But the, unofficial source states that Gurungs occupy a major portion i.e. about $20 \%$ among the competing candidates and about $22 \%$ in the recruited candidates.

33 Interview taken on $22^{\text {nd }}$ July, 2010, Pokhara.
We were so much shocked that those who have never smoked or drank yet, finished many bottles of beer and whiskey and many packets of cigarettes. One of our friends was not willing to return back to home. So, we stayed together for some days. Later on, we all convinced him and we all returned back to home. There is a high level frustration and it badly affects one life. ${ }^{34}$

It's very hard to recover from such kind of frustration. Sometimes it many even lead to drug addiction. Most of the candidates do not stay in the country to continue their study. They think that their contemporary friends have been successful to become lahure and now they will earn more. So, they try to find other foreign employment opportunities so that they can earn like their lahure friend. Only very few of the unsuccessful candidates remain in the home country to continue higher studies. Thus, the process of the recruitment is adversely affecting the higher education of Gurung youths.

Beside the negative impact, there are some positive impacts of British Gurkha Recruitment on the education of lahure community. The military service helped a significant portion of ex-soldiers to read and write." Moreover, on their return to the hills many of these soldiers infused their local communities with a positive attitude to schooling, and played a vital part on setting up schools around the country"(Caplan, 2003:61). The children of lahures are well benefited in attaining good education. "Whether stationed in Brunei or the United Kingdom, army wives and children are exposed to a world that offers a high standard of living, good educational and recreational facilities, and a set of value which is quite different from that of village" (Aryal, 1991:19). After their return to the homeland they join private boarding schools which are quite expensive and are of less access for the other ordinary people. The children of lahure who are born in Nepal are also benefited by such facility. Nowadays the facilities of a British lahure have significantly increased. The British Government has made the provisions of settlement in the U.K. for the Gurkha

\footnotetext{
$\overline{34}$ Interview taken on $25^{\text {th }}$ October, 2010, Pokhara.
} 
soldier who is retired after 1997 A.D. After the movement of GAESO and the other ex-Gurkha soldier's organizations, the British Government also has made the provisions of settlement in the U.K. for the ex-Gurkha soldier who had served in British army at least for four years. The dependent children of the ex-Gurkha solider can also get ILR ${ }^{35}$ card to remain in the U.K. So, many exGurkha and their dependent children are migrating towards the U.K. Thus, the children of British Gurkha army and ex-Gurkha army have access of better education in the U.K.

During the research it was found that most of the persons who have established themselves as good educational professionals belong to lahure family. They would not have been able to reach this stage without the support of their lahure father or brother. A lecturer at

P.N. Campus, who is a Ph.D. graduate, shares his experience as: My father was an ex-British Army and my brothers were also in British army. My parents always encouraged me to study. They used to say that they had to make their one son study high. My brothers also supported me. So, with the support of my parents and brother I am here on this stage. I didn't face any economic problem during the study due to their support. Without their support I would not have been in this stage. ${ }^{36}$

In the same way, another lecturer at P.N. campus remembers his father's support as:

I was always encouraged by my father in study. He used to say me to read up to higher level as I desire. Perhaps, he might have realized that he had to suffer in the army being an uneducated person. So, he always supported me and my junior brother for higher education. ${ }^{37}$

The person who recruits in the army stops his study but invests on the education of their children and relatives. So, the children of

\footnotetext{
${ }^{35}$ Indefinite Leave to Remain. It's the identity card issued by the U.K government for the immigrants to settle in U.K

36 Interview taken on $29^{\text {th }}$ October, 2010, Pokhara.

37 Interview taken on $29^{\text {th }}$ October, 2010, Pokhara.
}

British lahure are getting good opportunity of education. However, all the children of British lahure are not doing well in higher education because there is dominance of pro-lahure culture in the community. Only few of them emerge as good educated professionals due to the support of their family.

\section{Conclusion}

British Gurkha recruitment has been a major source of livelihood for the recruiting communities including Gurungs since a long time. Still today, many boys see their good fortune in it. There is a close relation between British Gurkha recruitment and higher educational achievement of Gurungs. Due to the high income, life long pension and other facilities, the youths are attracted to the British Gurkha army, rather than attaining higher studies. The socio-cultural circumstances also encourage them for the recruitment. Gurung society is characterized by an expensive life style and high cultural expenses. So, a British lahure receives a higher social value than an educated professional when the value is determined on the basis of economy. The preference for a lahure discourages the young men from attaining higher education. An educated professional receives enough social value only when he is successful to establish himself at the top level. If such social value was given to all Gurung youths during the initial period of their study, then the situation of higher education among the Gurungs would have been different.

The involvement of Gurung youths in the British army, the preparation process, social value of lahure and other pro-lahure and foreign employment culture are the major causes of under representation of Gurung in the higher education. Beside the negative impact, the children of the lahure are benefited in attaining better education which is a positive impact of the recruitment. But only few of them have been successful to establish themselves as good educated professionals and many others are left behind. So, the recruitment has more negative impact than positive. With the change in time, there are also some changing scenarios. There has been growing awareness about the higher education among the Gurungs. However, if they do not get fully aware in time and start to give high priority for higher 
education instead of British Gurkha recruitment, then they will be left far behind than other caste groups.

Nowadays, the Gurungs youths are not only limited in the recruitment of the British Gurkha army. They have reached to different parts of the world such as the U.S. A., Europe, East Asia and the Gulf. Thus, the practice of being lahure has now taken the extended form of foreign employment. This research has tried to analyze only the impact of the British Gurkha recruitment on the higher education of the Gurung young men. But the impact of overall foreign employment is not discussed. Moreover, the impact of the recruitment on the higher education of the female Gurung youths is not explained. All these will be important issues for further research.

\section{Acknowledgement}

This article is an outcome of the research fellowship program at Martin Chautari. So, first of all, I would like to thank Martin Chautari family for providing me this opportunity and necessary fund to carry out the research. Particularly, I am grateful to Dr. Pratayoush Onta for supervising me throughout the research period and giving valuable suggestions and comments in the preparation of this article. I am also grateful to Dr. Pramod Bhatta, Yam Pun and Sita Bhattarai of Martin Chautari for their kind support and suggestions in conducting the research. Similarly, I cannot forget the kind co-operation of Bharat Gurung, the president of Tamu Student Union of Kaski, during the field work at Pokhara without which I could not have completed this research.

\section{References}

Aryal, Manisha. (1991). 'To Marry a Lahuray' Himal 4 (3):19-19. Banskota, Purushottam. (1994). The Gurkha Connection: A History of the Gurkha Recruitment in the British Indian Army. Jaipur: Nirala Publications.

Bhatta, Pramod, Lila Adhikari, Mann Thapa and Ramesh Rai. (2008). Structures of Denial: Student Representation in Nepal's Higher Education. In Studies in Nepali History and Society 13 (2): 235-263.
Caplan, Lionel. (2003). Warrior Gentlemen, 'Gurkhas' in the Western Imagination. Kathmandu: Himal Books.

CBS (2001). Population Census of Nepal 2001. Kathmandu: CBS. Des Chene, Mary. (1991). Relics of Empire: A Cultural History of the Gurkhas, 1815-1987. Ph. D Dissertation, Stanford University.

Gould, Tony. (1999). Imperial Warriors: Britain and the Gurkhas. London: Granta.

Gurung, Birendra Singh. (2065). Status of Gurung in Higher Education: A Base Life Study. Unpublished Research Report submitted to Intellectuals Gurung Forum.

Onta, Pratyoush R. (1996). The Politics of Bravery: A History of Nepali Nationalism. Ph.D Dissertation, University of Pennsylvania.

Pignede, Bernard (1993) [1996]. The Gurungs: A Himalayan Population of Nepal. Kathmandu: Ratna Pustak Bhandar.

Pettigrew, Judith. (2000). Gurkhas in the Town: Migration, Language and Healing. In European Bulletin of Himalayan Research 19:7-39.

Ragsdale, Tod A. (1989). Once A Hermit Kingdom Ethnicity, Education and National Integration in Nepal. New Delhi: Manohar Publications.

Rai, Prakash. (2010). Lahuray Culture and Access to Higher Education: A Case from Rai Community. Unpublished Research Article submitted to Martin Chautari.

Rai, Pushpa Raj. (2058 V.S). The Social, Cultural, Economic and Political condition of Ex-British GURKHA: A Case Study of Ratanchha VDC. M.A. Dissertation, Department of Sociology/Anthropology. Trichandra Campus, Kathmandu.

Rao, C.N Shankar. (1990). Sociology : Primary Principles .New Delhi : S.Chand

Schaefer, Richard T. (2003). Sociology. New York : Mc Graw-Hill. UNDP (2004). Nepal Human Development Report 2004: Empowerment and Poverty Reduction. Kathmandu: UNDP, Nepal.

के.सी., सुरेन्द्र (२०६२) । गोर्खा भर्ती: कथा, व्यथा ₹ आन्दोलन । काठमाडौ: सविता प्रकाशन ।

(गुरुङ) थकाली, होमा (२०६७)। तमु गुरुङ जातिको: उत्पत्ति र धर्म-संस्कृति। काठमाडौ: लेखिका स्वयं। 